\title{
Isolation and Identification of Heavy Metal Tolerant Bacteria from Tannery Effluents
}

\author{
M Iqbal Hossain and M Nural Anwar* \\ Department of Microbiology, University of Chittagong, Chittagong - 4331, Bangladesh.
}

\begin{abstract}
The aim and objective of the study was to isolate and characterize heavy metal tolerant microorganisms from tannery effluents. Six effluent samples were collected aseptically and their physical and chemical parameters were determined. A total of $\mathbf{4 0}$ bacterial colonies were isolated from these effluent samples. Among them, six bacterial isolates were characterized provisionally as Alcaligenes aquamarinus, Bacillus coagulans, Bacillus firmus, Enterobacter cloacae, Pseudomonas alcaligens and Pseudomonas mendocina based on morphological, cultural and biochemical characteristics. The survibality and tolerance to heavy metals ( $\mathrm{Cr}$ and $\mathrm{Cu}$ ) of these isolates were examined. All the isolates were found to grow at high concentration of $\mathrm{CuSO}_{4}(95 \mathrm{ppm} / \mathrm{ml})$ and varying degrees of chromium $\left(\mathrm{K}_{2} \mathrm{Cr}_{2} \mathrm{O}_{7}\right)$. The highest tolerance was shown by Alcaligenes aquamarinus. These heavy metal tolerant organisms could be potential agents for bioremediation of heavy metals polluted environment.
\end{abstract}

Keywords: Heavy metal, Tolerance, Tannery effluent, Bioremediation

\section{Introduction}

The direct discharge of effluents from tanneries into bodies of water has become a growing environmental problem. Most of these wastewaters are extremely complex mixtures containing inorganic and organic compounds ${ }^{1}$. The tannery operation consists of converting the raw hide or skin into leather, which can be used in the manufacture of a wide range of products. Consequently, the tanning industry is a potentially pollutionintensive industry. Chemical impurities mostly comprise of the following dissolved substances: inorganic salt cations such as $\mathrm{Fe}^{2+}, \mathrm{Zn}^{2+}, \mathrm{Cu}^{2+}, \mathrm{Ca}^{+}, \mathrm{Na}^{+}$, etc., anion such as $\mathrm{SO}_{4}{ }^{2-}, \mathrm{NO}_{3}{ }^{-}, \mathrm{PO}_{4}{ }^{3-}$ ; organic parameters such as Dissolved Oxygen (DO), Total Dissolved Solids (TDS) ${ }^{2}$.

Heavy metal contamination is widespread. Heavy metals are often defined as a group of metals whose atomic density is greater than 5 gram per cubic centimeter ${ }^{3-5}$. In nature, there are about 50 heavy metals of special concern because of their toxicological effect to human beings and other living organisms like microorganisms ${ }^{6}$. Metals play a vital role in the metabolic processes of the biota. Some of the heavy metals are essential and are required by the organisms as micro nutrients (Co, $\mathrm{Cu}$, $\mathrm{Ni}, \mathrm{Fe}, \mathrm{Mn}$ and Zn, etc.) and are known as 'trace elements' ${ }^{6}$. They are involved in redox processes, in order to stabilize molecules through electrostatic interactions, as catalysts in enzymatic reactions, and regulating the osmotic balance ${ }^{7}$. On the other hand, some other heavy metals have no biological role and are detrimental to the organisms even at very low concentration (Cr, Cd, $\mathrm{Hg}, \mathrm{Pb}$, etc.). However, at high levels both of the essential and non-essential metals become toxic to the organisms as well as human being.

These heavy metals influence the microbial population by affecting their growth, morphology, biochemical activities and ultimately resulting in decreased biomass and diversity ${ }^{8}$. Heavy metals can damage the cell membranes, alter enzymes specificity, disrupt cellular functions and damage the structure of DNA. Toxicity of these heavy metals occurs through the displacement of essential metals from their native binding sites or through ligand interactions ${ }^{6}$. Also, toxicity can occur as a result of alterations in the conformational structure of the nucleic acids and proteins and interference with oxidative phosphorylation and osmotic balance ${ }^{6,9}$.

Due to the selective pressure from the metal in the growth environment, microorganisms have evolved various mechanisms to resist the heavy metal stress. Several metal resistance mechanisms have been identified: exclusion by permeability barrier, intra and extra cellular sequestration, active transport, efflux pumps, enzymatic detoxification, and reduction in the sensitivity of the cellular targets to metal ions ${ }^{6,9}$. Most mechanism reported involves the efflux of metal ions outside the cell, and genes for tolerance mechanisms have been found on both chromosomes and plasmids. Bacteria that are resistant to and grow on metals play an important role in the biogeochemical cycling of those metal ions.

* Corresponding author: 
In this perspective, many approaches have been used to assess the risk proposed by the contaminating metals in soil, water bodies etc. At present the tolerance of soil bacteria to heavy metals has been proposed as an indicator of the potential toxicity of heavy metals to other forms of biota ${ }^{10,11}$. Therefore, there is a dramatic increase in the interest on studying the interactions of heavy metals with microorganisms. The favored approach now is selecting the organism that can be used to develop tools to assess the metal levels in the environment. The objective of this study was to isolate and identify the bacteria from tannery effluent to determine their tolerance to chromium and copper.

\section{Materials and Methods}

\section{Collection of samples}

Six effluent samples were collected aseptically from Madina tannery and Rowshan tannery, Baluchara, Chittagong. The $\mathrm{pH}$, temperature and colour of the samples were recorded. Sterile glass bottles, conical flasks, polythene bags, cottons, forceps, and alcohol were used in collecting the samples and after that these were transported, brought to the laboratory and preserved at $4^{\circ} \mathrm{C}$.

\section{Isolation and enumeration of microorganisms}

Media namely Nutrient agar, Cetrimide agar, MacConkey agar and Eosin Methylene Blue agar were used for isolation of bacteria from tannery effluents. The inoculated agar plates were incubated at $37^{\circ} \mathrm{C}$ for $24-48$ hours in an incubator. After incubation, varied colonies were purified on Nutrient agar plates. Total bacterial count of the samples was determined by serial dilution followed by pour plate and spread plate methods in nutrient agar medium. All the cultures were stored at $4^{\circ} \mathrm{C}$.

\section{Characterization and identification of selected bacterial isolates}

Bacterial isolates were characterized and identified on the basis of their morphological, cultural, physiological and biochemical characteristics. The tests include gram staining, spore formation, motility, indole test, methyl red test, nitrate reduction test, oxidase test, catalase test, voges proskauer test, acid production after sugar utilization, $\mathrm{H}_{2} \mathrm{~S}$ production and gelatin liquefaction.

\section{Evaluation of metal tolerance}

The bacterial isolates were tested for their tolerance to chromium and copper by broth dilution method ${ }^{12}$. For this test, 10 different concentration viz. 1.0, 15.0, 30.0, 40.0, 50.0, 60.0, 70.0, 80.0, 90.0 and $95.0 \mathrm{ppm} / \mathrm{ml}$ of heavy metal (copper and chromium) containing nutrient broth medium was prepared and dispensed into the test tubes (10 ml/tubes) and sterilized in an autoclave. These modified broths were inoculated with the equal amounts of individual selected organism isolated from the industrial effluent by preparing suspension. For comparing the growth response at different concentration, one set of nutrient broth (without the heavy metal) containing test tubes were inoculated with the selected organisms and used as control. Then incubated at $37^{\circ} \mathrm{C}$ for 2 to 4 days and observed periodically.

\section{Results and Discussion}

The temperature, $\mathrm{pH}$, and total bacterial count of each sample are given in Table 1 . The temperature and $\mathrm{pH}$ of the collected samples were found to vary from 26 to $29^{\circ} \mathrm{C}$ and 5.7 to 12.2 respectively. The total bacterial count ranged from $10 \times 10^{3}$ to $92 \times 10^{3}$ (cfu/ml of sample). During the period of study, a total number of 40 bacterial colonies were isolated from 6 tannery effluent samples. Out of the 40 isolates, 14 isolates were selected for further study on the basis of their morphological and cultural diversities. Among the 14 isolates, 6 isolates showed tolerance to both chromium $\left(\mathrm{K}_{2} \mathrm{Cr}_{2} \mathrm{O}_{7}\right)$ and copper $\left(\mathrm{CuSO}_{4}\right)$ even at their high concentrations. These isolates were found belong to 4 genera, such as Alcaligenes, Bacillus, Enterobacter and Pseudomonas while compared with the standard description of "Bergey's Manual of Determinative Bacteriology", $8^{\text {th }}$ ed. ${ }^{13}$. An attempt was made to identify them up to species level and provisionally identified as Alcaligenes aquamarinus $\left(\mathrm{S}_{5} \mathrm{I} / 1\right)$, Bacillus coagulans $\left(\mathrm{S}_{4} \mathrm{I} / 3\right)$, Bacillus firmus $\left(\mathrm{S}_{5} \mathrm{I} / 6\right)$, Enterobacter cloacae $\left(\mathrm{S}_{5} \mathrm{I} / 2\right)$, Pseudomonas alcaligens $\left(\mathrm{S}_{4} \mathrm{I} /\right.$ 1) and Pseudomonas mendocina $\left(\mathrm{S}_{4} \mathrm{I} / 2\right)$ (Table 2$)$.

Table 1. Temperature, $p H$ and microbial load of the effluent samples

\begin{tabular}{lccc}
\hline Sample No. & $\mathrm{pH}$ & Temperature $\left({ }^{\circ} \mathrm{C}\right)$ & $\begin{array}{c}\text { Total bacterial } \\
\text { count }(\mathrm{cfu} / \mathrm{ml})\end{array}$ \\
\hline 1. & 5.8 & $29^{\circ} \mathrm{C}$ & $23 \times 10^{3}$ \\
2. & 5.7 & $26^{\circ} \mathrm{C}$ & $65 \times 10^{3}$ \\
3. & 12.2 & $28^{\circ} \mathrm{C}$ & $92 \times 10^{3}$ \\
4. & 10.2 & $27^{\circ} \mathrm{C}$ & $10 \times 10^{3}$ \\
5. & 10.1 & $26^{\circ} \mathrm{C}$ & $24 \times 10^{3}$ \\
6. & 8.7 & $27^{\circ} \mathrm{C}$ & $42 \times 10^{3}$ \\
\hline
\end{tabular}

When natural environments are contaminated with pollutants, the indigenous microbial communities are likely to contain microbial populations of different taxonomic characteristics, which are capable of degrading the contaminating chemicals ${ }^{14}$. Prior the screening of heavy metal tolerant microorganisms, the bacterial populations were estimated in each original sample. Appreciable number of bacteria has been found to exist in the samples.

Since tannery effluent contain large amount of heavy metals, the effect of $\mathrm{Cr}$ and $\mathrm{Cu}$ on bacterial growth and the ability to detoxify the pollutants in vitro was the important part of the present study. Microbial tolerance to $\mathrm{Cr}$ and $\mathrm{Cu}$ was studied visually. Chromium (Cr) tolerance studies on bacteria carried out on solid media could be unsatisfactory since the Cr can be bound to the agar of components in the agar15, 16. In our study, the test was carried out in nutrient broth supplemented with chromium and copper of different concentrations range from $1.0 \mathrm{ppm}$ to $95 \mathrm{ppm}$. It was found that, the growth of all the bacterial isolates decreased with increasing concentration of $\mathrm{K}_{2} \mathrm{Cr}_{2} \mathrm{O}_{7}$ or $\mathrm{CuSO}_{4}$ (Table 3 \& 4). Isolate Pseudomonas mendocina $\left(\mathrm{S}_{4} \mathrm{I} / 2\right)$ was able to tolerate $\mathrm{Cr}\left(\mathrm{K}_{2} \mathrm{Cr}_{2} \mathrm{O}_{7}\right)$ up to 50 
Table 2. Morphological, physiological and biochemical characteristics of bacterial isolates

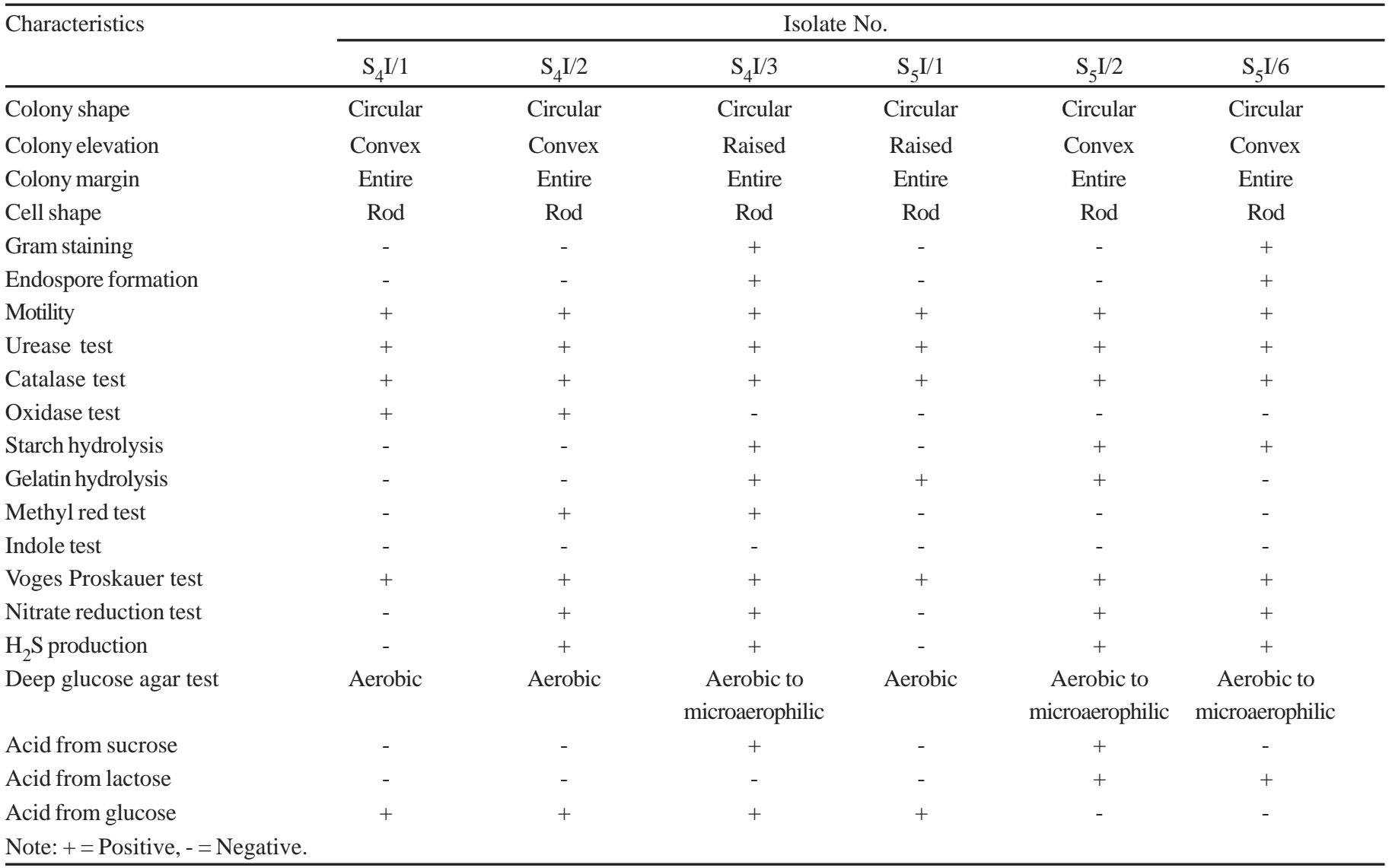

Table 3. Heavy metal $\left(\mathrm{K}_{2} \mathrm{Cr}_{2} \mathrm{O}_{7}\right)$ tolerance profile of selected bacterial isolates.

\begin{tabular}{|c|c|c|c|c|c|c|c|c|c|c|c|}
\hline $\begin{array}{l}\text { Isolate } \\
\text { No. }\end{array}$ & $\begin{array}{l}\text { Growth activity } \\
\text { (turbidity) in } \\
\text { nutrient broth }\end{array}$ & \multicolumn{9}{|c|}{ Growth (tolerance) at various ppm } & 95 \\
\hline $\mathrm{S}_{4} \mathrm{I} / 1$ & +++ & +++ & +++ & ++ & + & + & + & + & - & - & - \\
\hline $\mathrm{S}_{4} \mathrm{I} / 2$ & +++ & +++ & ++ & ++ & + & + & - & - & - & - & - \\
\hline $\mathrm{S}_{4} \mathrm{I} / 3$ & +++ & +++ & ++ & ++ & + & + & + & - & - & - & - \\
\hline $\mathrm{S}_{5} \mathrm{I} / 2$ & +++ & +++ & +++ & +++ & +++ & +++ & +++ & +++ & ++ & + & - \\
\hline $\mathrm{S}_{5} \mathrm{I} / 6$ & +++ & +++ & +++ & +++ & ++ & ++ & ++ & + & + & - & - \\
\hline
\end{tabular}

Note: + = Positive (+ = scanty, $++=$ moderate, $+++=$ heavy), - = Negative.

Table 4. Heavy metal $\left(\mathrm{CuSO}_{4}\right)$ tolerance profile of selected bacterial isolates.

\begin{tabular}{|c|c|c|c|c|c|c|c|c|c|c|c|}
\hline $\begin{array}{l}\text { Isolate } \\
\text { No. }\end{array}$ & $\begin{array}{l}\text { Growth activity } \\
\text { (turbidity) in } \\
\text { nutrient broth }\end{array}$ & \multicolumn{9}{|c|}{ Growth (tolerance) at various ppm } & 95 \\
\hline $\mathrm{S}_{4} \mathrm{I} / 1$ & +++ & +++ & +++ & +++ & +++ & +++ & +++ & ++ & + & + & + \\
\hline $\mathrm{S}_{4} \mathrm{I} / 2$ & +++ & +++ & +++ & +++ & ++ & ++ & ++ & + & + & + & + \\
\hline $\mathrm{S}_{4} \mathrm{I} / 3$ & +++ & +++ & +++ & +++ & +++ & ++ & ++ & + & + & + & + \\
\hline $\mathrm{S}_{5} \mathrm{I} / 2$ & +++ & +++ & +++ & +++ & +++ & +++ & +++ & +++ & ++ & + & + \\
\hline $\mathrm{S}_{5} \mathrm{I} / 6$ & +++ & +++ & +++ & +++ & +++ & +++ & ++ & + & + & + & + \\
\hline
\end{tabular}

Note: + = Positive (+ = scanty, $++=$ moderate, $+++=$ heavy), - = Negative. 
ppm. The isolates Bacillus coagulans $\left(\mathrm{S}_{4} \mathrm{I} / 3\right)$ and Pseudomonas alcaligens $\left(\mathrm{S}_{4} \mathrm{I} / 1\right)$ were found to tolerate $\mathrm{Cr}\left(\mathrm{K}_{2} \mathrm{Cr}_{2} \mathrm{O}_{7}\right)$ up to 60 and $70 \mathrm{ppm}$ respectively. The isolates Bacillus firmus $\left(\mathrm{S}_{5} \mathrm{I} /\right.$ 6) and Enterobacter cloacae $\left(\mathrm{S}_{5} \mathrm{I} / 2\right)$ were able to tolerate $\mathrm{Cr}$ $\left(\mathrm{K}_{2} \mathrm{Cr}_{2} \mathrm{O}_{7}\right)$ up to 80 and 90 ppm respectively while the isolate Alcaligenes aquamarinus $\left(\mathrm{S}_{5} \mathrm{I} / 1\right)$ was found to grow even at the concentration of $95 \mathrm{ppm} \mathrm{Cr}\left(\mathrm{K}_{2} \mathrm{Cr}_{2} \mathrm{O}_{7}\right)$. All the bacterial isolates could grow in the presence of 95 ppm $\mathrm{CuSO}_{4}$.

All the bacterial isolates used in this study showed very highlevel resistance against potassium dichromate and copper sulphate in nutrient broth and the results are in concurrence with the results of many scientists. Bacterial tolerance to chromate $\left(\mathrm{CrO}_{4}{ }^{2-}\right)$ has been found in several Pseudomonas strains ${ }^{17}$. Basu et al. ${ }^{18}$ isolated chromium resistant bacteria from effluent of tanneries and found that they could resist up to 250 $\mu \mathrm{g} / \mathrm{ml}$ of $\mathrm{Cr}$ (VI) in the medium. Megharaj et al. ${ }^{19}$ also reported strains, which were isolated from polluted soil, could resist up to $100 \mu \mathrm{g} / \mathrm{ml}$ of $\mathrm{Cr}$ (VI). Strains reported by Filali et al. ${ }^{20}$ also exhibited different heavy metals resistances.

Resistance of toxic metals in bacteria probably reflects the degree of environmental contamination with these substances and may be directly related to exposure of bacteria to them ${ }^{21}$. However, unpolluted environments may also harbor metal resistant organism or organisms that readily adapt to high concentrations of metals. The incidence of plasmid bearing strains is more in polluted sites than in the unpolluted zone ${ }^{22}$. Baath $^{23}$ found that although exposure to metals enhances resistance, the fact that resistant bacteria are found in environments never exposed to high concentrations of heavy metals indicates that heavy metal tolerant species already exist in non-polluted habitats.

Natural habitats are generally characterized by the coexistence of a large number of toxic and non-toxic cations and therefore it is necessary to study multiple metal effects on the physiology and biochemistry of microorganisms ${ }^{24}$. All the six bacterial isolates used in this study were found tolerant to multiple metals. These observations assume great significance because effluent from any metal-related industry contains several metal ions/ contaminants. Furthermore, when there are other metal contaminants, it might be practical to use the heavy metal tolerant bacteria to remove heavy metals ${ }^{25}$.

The industrial effluents are enriched medium to grow and spread of microbial population, which are resistant to different metals. The identification of resistance against different metals may provide a useful tool for the simultaneous monitoring of several toxic pollutants in the environment. It is clearly indicated that domestic waste and industrial waste are responsible for the development of bacterial resistance. All the bacterial isolates used in this study showed very high-level resistance against chromium and copper. The future prospect lies in the application of these bacteria for purposes like heavy metal remediation and potential use in extracting rare metals from dilute solutions or removing toxic metals from industrial effluents.

\section{References}

1. Fu LJ, Stares RE \& Stahy RG. 1994. Assessing acute toxicities of pre and post treatment industrial wastewaters with Hydra attenata: A comparative study of acute toxicity with the Fatheadmonnows, Phimephales, Promelas. Environ Toxicol Chem. 13: 563-569.

2. Bosnic M, Buljan J \& Daniels RP. 2000. Regional program for pollution control in the Tanning industry. US/RAS/92/120 in South-East Asia, pp 1-14.

3. Gadd GM. 1992. Metals and microorganisms: A problem definition. FEMS Microbiol Lett 100. pp 197-204.

4. Nies DH. 1999. Microbial heavy metal resistance. Appl microbiol biotech. 55, pp: 730-750.

5. Antonovics J, Bradshaw AD \& Turner RC. 1971. Heavy metal tolerance in plants. Adv Ecol Rev. 7: 1-85.

6. Bruins MR, Kapal S \& Oehme WF. 2000. Microbial resistance to metals in the environment. Ecotoxocol Environ Safety. 45:198-207.

7. Hussein H, Farag S, Kandil K \& Moawad H. 2005. Tolerance and uptake of heavy metals by pseudomonads. Pro Biochem. 40: 955-961.

8. Roane TM \& Pepper IL. 2000. Microbial responses to environmentally toxic cadmium. Microbial Ecol. 38: 358-364.

9. Poole RK \& Gadd GM. 1989. Metals: Microbe Interactions, pp 1-37. IRL Press, Oxford.

10. Olson BH \& Thronton I. 1982. The resistance patterns to metals of bacterial pollutions in contaminated land. J Soil Science. 33: 271-277.

11. Hassen A, Saidi N, Cherif M \& Boudabous A. 1998. Resistance of environmental bacteria to heavy metals. Biores Technol. 64: 7-15.

12. Calomoris JJ, Armstrong TL \& Seidler RJ. 1984. Association of metaltolerance with multiple antibiotic resistances of bacteria isolated from drinking water. Appl Environ Microbiol. 47: 1238-1242.

13. Buchanan RE \& Gibbons NE. 1974. Bergey's Manual of Determinative Bacteriology, $8^{\text {th }}$ edn, pp 1268. The Williams and Wilkins Company, Baltimore.

14. Bartha R \& Atlas RM. 1977. The microbiology of aquatic oil spills. Adv Appl Microbiol. 22: 225-266

15. Ramamoorthy S \& Kushnor DJ. 1975. Binding of mercuric and other metal ions by microbial growth media. Microbial Ecol. 2:162-175.

16. Washington II JA, Snyder RJ, Kohner PC, Wiltse CG, Itstrup DM \& McCall JT. 1978. Effect of cation content of agar on the activity of gentamycin, tobramycin and amikacin against Pseudomonas aeruginosa. J. Infectious Diseases. 137: 103-111.

17. Bopp LH, Chakrabarty AM \& Ehrlich ML. 1983. Chromate resistance plasmid in Pseudomonas aerogenes. J. Bacteriol. 155:1105.

18. Basu M, Bhattacharya S \& Paul AK.1997. Isolation and characterization of chromium resistant bacteria from tannery effluent. Bull Environ Contam Toxicol. 58: 535-542.

19. Megharaj M, Avudainayagam S \& Neidu R. 2003. Toxicity of hexavalent chromium and its reduction by bacteria isolated from soil contaminated with tannery waste. Curr Microbiol. 47: 51-54.

20. Filali-Meknassi Y, Tyagi RD \& Narasiah KS. 2000. Simultaneous sewage sludge digestion and metal leaching: effect of aeration. Pro Biochem. 36: 263-273.

21. Aiking H, Stinamn A, Ganderen C, Heerikhuizen H, Riet J. 1984. Inorganic phosphate accumulation and cadmium detoxification in Klebsiella aerogenes NCTC 418 growing in continuous culture. Appl Environ Microbiol. 47:374-377.

22. Malik A \& Jaiswal R. 2000. Metal resistance in Pseudomonas strains isolated from soil treated with industrial wastewater. W J Microbiol Biotechnol. 16:177-182.

23. Baath E. 1989. Effect of heavy metals in soil on microbial processes and populations. Water Air Soil Pollut. 47:335-379.

24. Verma SK \& Singh SP. 1995. Multiple chemical resistance in the cyanobacterium, Nostoc muscorum. Bull Environ Contam Toxicol. 54: 614-619.

25. Lovely DR. 1995. Bioremediation of organic and metal contaminants with dissimilatory metal reduction. J Ind Microbiol. 14: 85-93. 